\title{
Characteristics and evolution of strike-slip tectonics of the Liaohe Western Sag, Bohai Bay Basin*
}

\author{
Tong Hengmao $^{1 * *}$, Yu Fusheng ${ }^{1}$ and Geng Changbo ${ }^{2}$ \\ ${ }^{1}$ Key State Laboratory of Oil and Gas Resources and Exploration, China University of Petroleum, Beijing 102249, China \\ ${ }^{2}$ CNPC International Research Center, Beijing 100083, China
}

\begin{abstract}
Because of its rich oil and gas resources and the special tectonic location of the Liaohe Western Sag (the Tanlu Fault traverses the sag), Bohai Bay Basin, a detailed study of its strike-slip tectonics is significant in revealing the sag's tectonic evolution, its control on hydrocarbon accumulation, and the activity history of the northern section of the Tanlu Fault in the Cenozoic. Through systematic structure analysis of 3D seismic data of the Liaohe Western Sag, combined with balanced section analysis, a variety of structural features in relation to right-lateral strike-slip faults, such as echelon normal faults, "comb" structure, "flower" structure, "interpretable" and "buried" strike-slip faults have been revealed exist in the Liaohe Western Sag. According to the research in this paper, the complex structural phenomena in the Liaohe Western Sag could be reasonably interpreted as right-lateral strike-slip activity and the strike-slip activities of the Liaohe Western Sag began in the early Oligocene. The activity was weak at the beginning $\left(\mathrm{E}_{3 \mathrm{S1}-2}\right)$, then strengthened gradually and reached its strongest level in the late Oligocene $\left(\mathrm{E}_{3 \mathrm{~d} 1}\right)$. In the Miocene, the strike-slip activity was low and then strengthened significantly once again from the Pliocene to the present. It is speculated that the entire northern section of the Tanlu Fault has had a similar evolution history since the Oligocene.
\end{abstract}

Key words: Bohai Bay Basin, Western Sag, Tanlu Fault, strike-slip tectonics, tectonic evolution

\section{Introduction}

The Liaohe Western Sag has always been given a lot of attention by researchers for the following reasons. 1) Rich oil and gas resources. It is one of the richest oil and gas bearing geological units and one of the most important oil production bases (Li et al, 2007; Shan et al, 2005). 2) Complicated and multiple geological phenomena. 3) Traversed by the Tanlu Fault. 4) High exploration level with abundant drilling (more than 15,000 wells) and testing data (3D seismic data cover the entire area).

The strike-slip activity of the Liaohe Western Sag has been known by researchers for a long time. In the first academic conference on the Tanlu Fault in 1980, it was presented that the Tanlu Fault traverses the Liaohe Depression, including Liaohe Eastern Sag and Western Sag (Yao and Fang, 1981). Hong and Yang (1984) presented that Taian Dawa Fault, the controlling fault of the Liaohe Western Sag, is the western of the two sub-faults of the Tanlu Fault in the Liaohe Depression. Xu (1993), Xu and Ma (1992), Xu et al $(1984 ; 1987 ; 1995)$ and Ma (1995) presented the three evolution stages of the Tanlu Fault $\left(\mathrm{J}-\mathrm{K}_{1}\right.$, left-lateral strike-slip stage; $\mathrm{K}_{2}-\mathrm{E}_{2}$, extensional and rifting

\footnotetext{
*National Natural Science Foundation (40772086). Common advanced projects of CNPC oil and gas exploration (07-01C-01-04)

**Corresponding author. email: tonghm@cup.edu.cn

Received January 7, 2008
}

stage; $\mathrm{E}_{3}-\mathrm{Q}$, nearly east-west compression and short rightlateral strike-slip stage). Although they did not point out the right-lateral strike-slip function of the Liaohe Western Sag in the Cenozoic directly, it was widely recognized thereafter. Liao and Yao (1996) studied the structure of the Western Sag relatively systematically and discussed the distribution and activity of the Tanlu Fault in the Liaohe Depression, and pointed out clearly the right-lateral strike-slip activity of the Liaohe Western Sag in the Cenozoic (Liao and Yao, 1996). In addition, some other researchers also discussed the strike-slip activity of the Liaohe Western Sag (Qi, 1995; You et al, 2006; Yang et al, 2006; Yu et al, 2007). However, some important problems had not yet solved clearly. 1) Specific indications and characteristics of strike-slip structure. 2) Exact timing of strike-slip activity. 3) Detailed evolution stage of strike-slip intensity. 4) The control and influence of strike-slip on the sag formation and evolution, including the control and influence on the formation and evolution of different areas and different structural zones.

Through integrated 3D seismic data interpretation and analysis of the entire Western Sag, combined with sandbox modeling and cross-section research, the problems mentioned above were studied and discussed in this paper. And according to our research, 1) A variety of indications in relation to right-lateral strike-slip exist in the Liaohe Western Sag. 2) Strike-slip activity played an important role in controlling the structural deformation of the Liaohe Western Sag in the Cenozoic. 3) Right-lateral strike-slip is the major 
type of strike-slip activity. 4) The strike-slip activities of the Liaohe Western Sag began from $\mathrm{E}_{3 \mathrm{~S} 1-2}$ in the early Oligocene. The activity intensity was weak at the beginning and reached its strongest level in the late Oligocene $\left(E_{3 \mathrm{~d} 1}\right)$. Significant strike-slip activity began from the Neogene to the Quaternary, and continued to the present time. The above conclusions are helpful for further oil and gas exploration in the Liaohe Western Sag and provide indications and clues for the future study of the Tanlu Fault activity in the Cenozoic.

\section{Regional geological setting}

The Liaohe Western Sag is a negative sub-structure unit, which is located in the northeast of the Bohai Bay Basin and the western sub-fault of the Tanlu Fault traverses the sag (Fig. 1). The Western Sag is adjacent to the Liaohe Eastern Sag in the east (separated by the Central Uplift), and is boarded by the Yanshan Folding Zones in the west, the Liaodong Bay Sag in the south and the Liaohe Northern Sag in the north. Its area is $3,000 \mathrm{~km}^{2}$ and it is one of the rich oil and gas sags in the Bohai Bay Basin.

The Bohai Bay Basin, where the Liaohe Western Sag is located, is a rifting basin of the Cenozoic, and has evolved through two important stages of rifting in the Paleocene and a depression stage in the Neogene. Thick Cenozoic strata deposited in the Liaohe Western Sag, including the Fangshenpao Formation $\left(\mathrm{E}_{1 \mathrm{f}}\right)$, Shahejie 4 (Sha 4) Member $\left(E_{2 s 4}\right)$, Shahejie 3 (Sha 3) Member $\left(E_{2 s 3}\right)$, Shahejie 1-2 (Sha 1-2) Members $\left(E_{3 s 1-2}\right)$, Dongying Formation $\left(E_{3 \mathrm{~d}}\right)$, Guantao Formation $\left(\mathrm{N}_{1 \mathrm{~g}}\right)$, Minghuazhen Formation $\left(\mathrm{N}_{2 \mathrm{~m}}\right)$ and Quaternary $(\mathrm{Q})$ layers. Its maximum thickness is up to $8000 \mathrm{~m}$. Continental clastic rocks are the main sedimentary rocks, including igneous rocks and a small amount of carbonate rocks. Drilling data reveal that the basement includes Archaeozoic crystalline metamorphic rocks, middle and upper Proterozoic carbonate and clastic rocks, Paleozoic carbonate rocks, and Cenozoic igneous rocks and clastic rocks. The reservoir beds are the sandstone of Sha 4 Member, Sha 3 Member, Sha 1-2 Members and carbonate and metamorphic rocks of the buried hill basement.

\section{Characteristics and indications of strike- slip tectonics}

Systematical structural analysis of the Liaohe Western Sag shows obvious characteristics of strike-slip tectonics, and plenty of strike-slip indications are recognized in the Western Sag, including 1) A basin-sized echelon faults zone; 2) Identified angle between the strike of sag axis and the strike of normal fault; 3) Development of a "comb" structure; 4) Existence of typical indications of strike-slip tectonics in the profile; 5) Co-existence of all kinds of structural styles resulting from strike-slip; 6) Co-existence of "interpretable" and "buried" strike-slip faults. All these characteristics will be elaborated below.

\subsection{Basin-sized echelon normal faults zone}

Through systematical structural interpretation and analysis, a magnificent basin-sized echelon normal faults

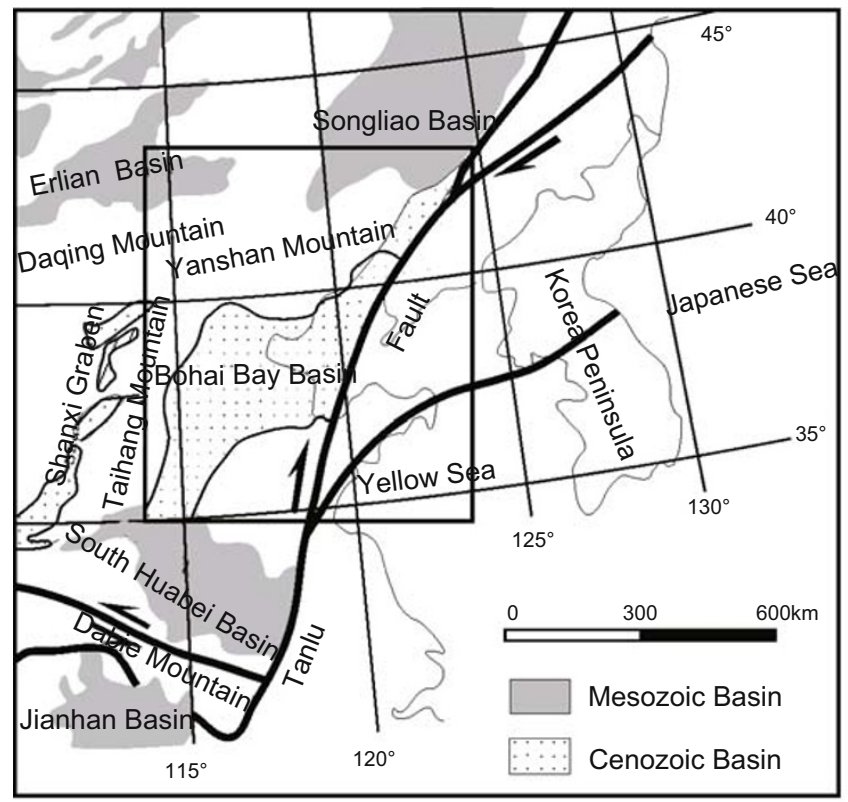

(a)

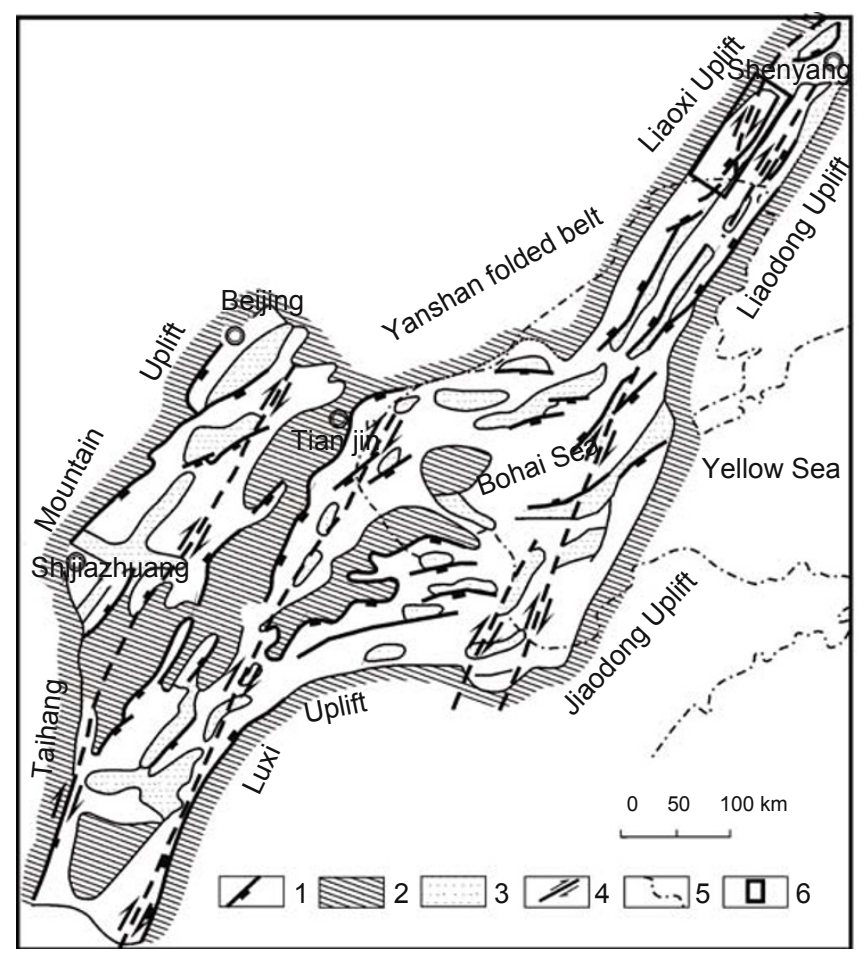

(b)

Fig. 1 (a) Bohai Bay Basin regional tectonic framework map (according to Meng (2003), the box is the region of the next map (b).) (b) Tectonic framework map of Bay Basin Program (according to Lu et al (1997)) 1 Paleocene boundary normal fault; 2 - Paleocene uplift area; 3 - Uplift or low uplift zone in the basin; 4 - Trunk basement strike-slip fault or concealed strike-slip fault; 5 - Coastline; 6 - Range of Liaohe Western Sag under study

zone is recognized and identified in the Western Sag (Fig. 2). This echelon normal faults zone is present in the southern and central Sag, and is developed in the bottom of $\mathrm{E}_{3 \mathrm{~s} 1-2}, \mathrm{E}_{3 \mathrm{~d}}$, $\mathrm{N}_{1 \mathrm{~g}}$ and $\mathrm{N}_{2 \mathrm{~m}}$, comprising of southward dipping, gradual-drop step-like normal faults (Fig. 3). Echelon faults are clearly developed in the bottom of $\mathrm{E}_{3 \mathrm{~d}}$ with a large number and 


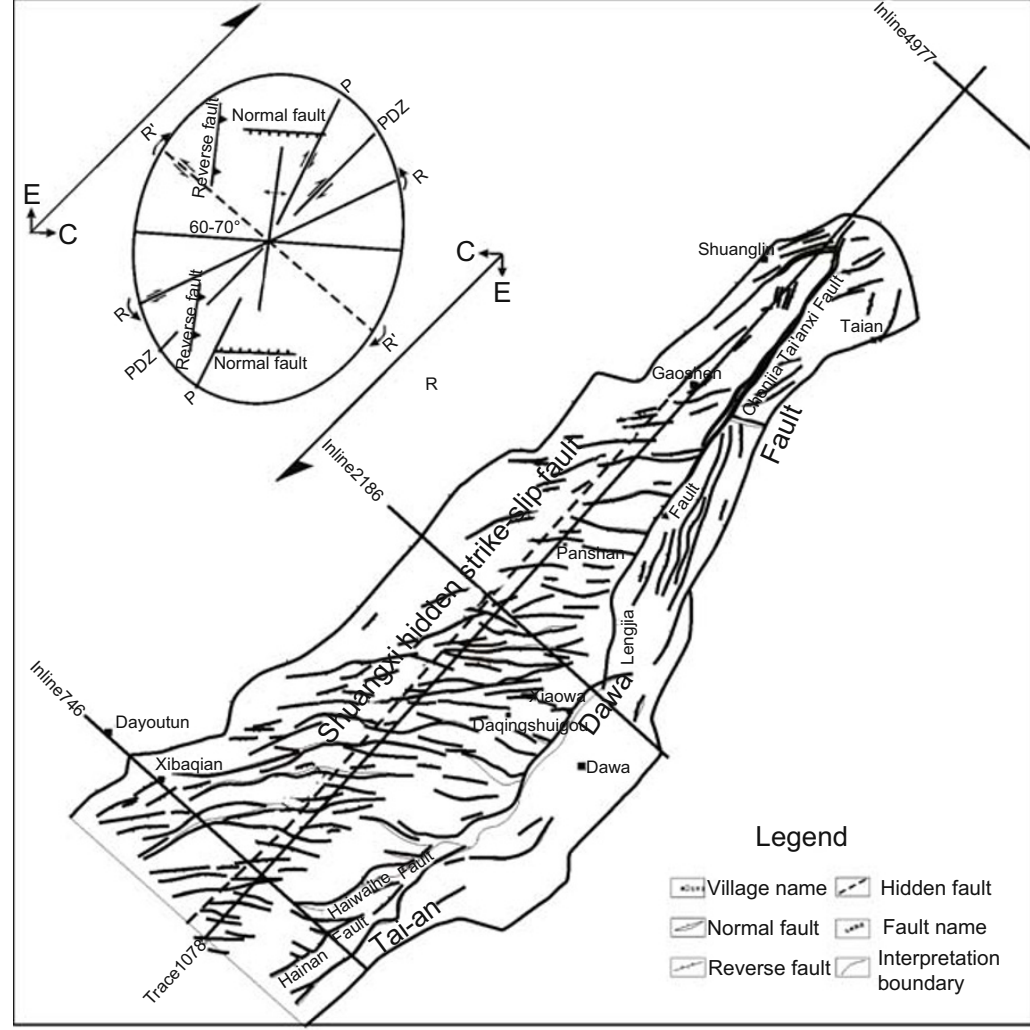

Fig. 2 Fault system map at Dongying Formation bottom in the Western Sag

direction of the sag. Whereas in sags formed by strike-slip activity, the average strike direction has an included angle of $40-50^{\circ}$ to the axial direction of the sag. So the $42^{\circ}$ included angle between the normal fault developed in and above the bottom of $E_{3 s 1-2}$ and the axial direction of the sag is one of the indication of strike-slip activity, and it is also the evidence of strike-slip tectonics.

\subsection{Development of planar "comb" structure}

In the structure contours of $\mathrm{E}_{3 \mathrm{~s} 1-2}, \mathrm{E}_{3 \mathrm{~d}}, \mathrm{~N}_{1 \mathrm{~g}}$ and $\mathrm{N}_{2 \mathrm{~m}}$, two typical "comb" structures are identified with major controlling faults of the Taian Dawa, Haiwahe and Lengjia-Chenjia Faults. The strikes of these faults are north-east and almost similar to the axial direction of the sag.

A "comb" structure, also called "broom" structure, is defined as a series of normal faults converge onto one strike-slip control fault to form a combined structure. The development of a "comb" structure is also important evidence of the existence of strike-slip structures.

\subsection{Existence of typical indications of strike-slip tectonics}

The indications of strike-slip structure in the Liaohe Western Sag include negative flower

relatively long extension length. The distribution of echelon faults in the bottom of $E_{3 s 1-2}$ was similar to $E_{3 \mathrm{~d}}$, because the echelon normal faults developed in $\mathrm{E}_{3 \mathrm{~d}}$ cut down the $\mathrm{E}_{3 \mathrm{~s} 1-2}$ strata. The development of echelon normal faults decreased in the bottom of $\mathrm{N}_{1 \mathrm{~g}}$ and $\mathrm{N}_{2 \mathrm{~m}}$, because most of the secondary or lower grade normal faults in the echelon normal faults zone stopped their activity after the Neogene. The existence of the echelon normal faults zone is important evidence of the existence of strike-slip faults.

\subsection{Included angle between the axial direction of sag and the strike of normal fault}

Normal faults development is stronger than thrust, and the normal faults developed in the bottom of $E_{3 s 1-2}, E_{3 \mathrm{~d}}, \mathrm{~N}_{1 \mathrm{~g}}$ and $\mathrm{N}_{2 \mathrm{~m}}$ have a specific included angle (Fig. 2, Fig. 4) to the axial direction of the sag. According to the statistical data, the included angles are $41^{\circ}, 42^{\circ}, 44^{\circ}$ and $44^{\circ}$ respectively.

For those sags formed by extension and compression, the average strike direction is almost the same with the axial structure and positive flower structure. Typical negative flower structures developed in the Panshan sag which is in the west of the Xinglongtai Buried Hill in the center of the sag (Fig. 5) and positive flower structure developed in the west of Niuxintuo inversion structure in the north of the Sag (Fig. 6). The recognition of flower structures is an important indication of strike-slip tectonics.

\subsection{Co-existence of all kinds of structural styles of strike-slip}

The Liaohe Western Sag is known as a geological palace by the Liaohe Oilfield Company, not only because of all kinds of strata and rocks from Archeozoic to Cenozoic encountered by drilling, but also because of the co-existence of extensional structures, compressional structures and inversion structures in the Cenozoic (Fig. 5), and this characteristic is very unusual in the entire Bohai Bay Basin.

Systematical structural interpretation and analysis show that there is a particularly regular distribution of different

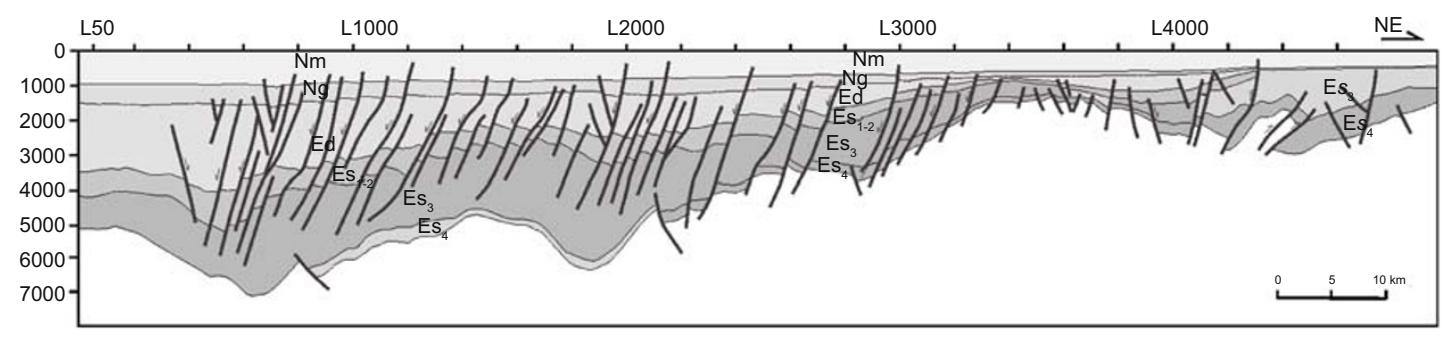

Fig. 3 Longitudinal structural profile of Western Depression (trace 1078 line) (location of the line see Fig. 2) 
structural styles, that is to say, the strike of the normal fault is nearly west-east, the strike of the thrust is nearly north-south, the strike of the strike-slip fault is north-east, the strike of the compresso-shear fault is north-north-east and the strike of the tenso-shear fault is north-east-east. This regularity can be successfully explained by Harding's strike-slip strain-ellipse (Fig. 2, Fig. 4). The co-existence of all kinds of structural styles and the ideal matching of all kinds of structural elements and right-lateral strain-ellipse is important evidence of strike-slip activity.

\subsection{Co-existence of "interpretable" and "buried" strike-slip faults}

An "interpretable" strike-slip fault is defined as a strikeslip fault which was developed into the overlying strata and can be recognized in the seismic sections. Whereas, a "buried" strike-slip fault is defined as a strike-slip fault which was activated in the basement and did not cut through the overlying strata while obviously controlling and influencing the structural deformation of the sedimentary overlying strata.

According to our research, "interpretable" strike-slip faults are developed in the eastern area of the sag, including the Hainan, Haiwahe, Taian Dawa, Lengjia, Chenjia-Tai'anxi and Niuxintuo Faults (Fig. 2, Fig. 4). The Shuangxi fault is identified as a "buried" strike-slip fault and this fault forms part of a newly-recognized and newly-identified "buried" fault zone (Fig. 2, Fig. 4). These faults have played an important role in controlling the sag's formation, evolution and hydrocarbon accumulation.

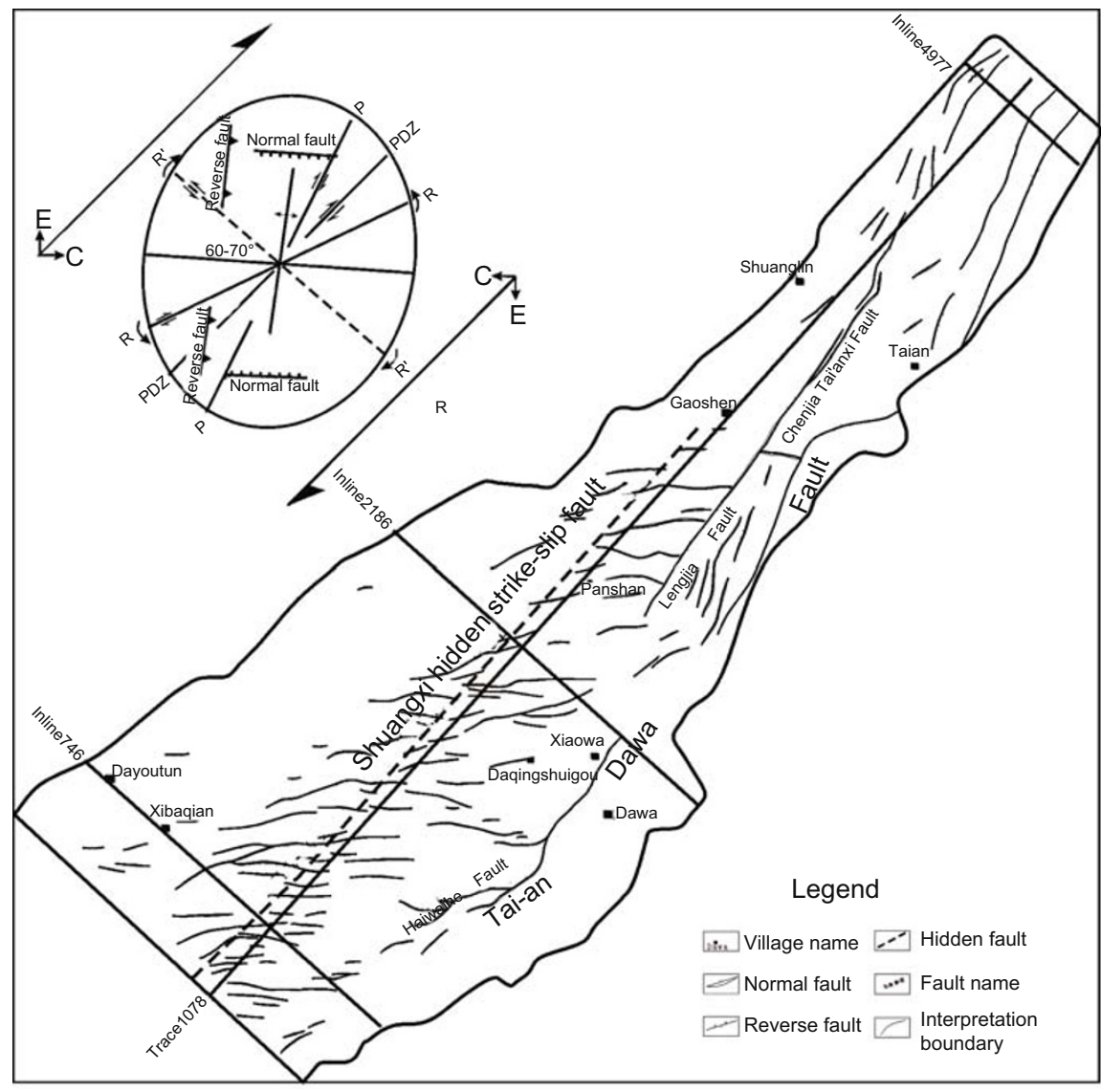

Fig. 4 Fault system map at Guantao Formation bottom in the Western Sag

\section{Style of strike-slip activity}

Right-lateral strike-slip activity was identified by many researchers after Xu Jiawei's representative systematic study of the Tanlu Fault. According to our research, echelon normal faults, "comb" structure and the distribution of different structural styles (east-west striking normal faults, north-south striking thrusts and north-east strike-slip faults) indicate that the strike-slip activity is right-lateral which confirms the former understanding about the strike-slip activity style of the Liaohe Western Sag.

The right-lateral strike-slip activity of the Liaohe Western Sag is not a pure strike-slip activity but has different appearances in different areas, which appear to be strikeslip tenso-shear in the south, compresso-shear and tensoshear complex area in the center, and compresso-shear in the north. All the strike-slip displacements do not focus on the "interpretable" faults, but are transferred into extensional deformation or compressional deformation, and strike-slip deformation is almost entirely transferred to extensional deformation in the south and center of the sag (including Qingshui Depression and Panshan-Chenjia Depression). Different kinds of complicated structural phenomena in the Liaohe Western Sag could be explained by strike-slip activity.

\section{History of strike-slip activity}

Through systematic structural interpretation and analysis, the Sha 4 Member $\left(E_{2 s 4}\right)$, Sha 3 Member $\left(E_{2 s 3}\right)$, Sha 1-2 Member $\left(E_{3 s 1-2}\right)$, Dongying Formation $\left(E_{3 \mathrm{~d}}\right)$, and GuantaoQuaternary (N-Q) in the Cenozoic respectively represent the five formation and evolution stages of the Cenozoic basin (Table 1). And these five stages are primary rifting stage $\left(\mathrm{E}_{2 \mathrm{~s} 4}\right)$, strong rifting stage $\left(E_{2 s 3}\right)$, transition stage from rifting to depression $\left(\mathrm{E}_{3 \mathrm{~s} 1-2}\right)$, differential uplifting and subsiding stage $\left(\mathrm{E}_{3 \mathrm{~d}}\right)$ and depression stage (N-Q). According to our research, the strike-slip activity of the Liaohe Western Sag began from the transition stage from rifting to depression $\left(\mathrm{E}_{3 \mathrm{~s} 1-2}\right)$, was activated most strongly in $\mathrm{E}_{3 \mathrm{~d} 1}$, and kept being activated from Tertiary to Quaternary (Table 1). The evidence is presented as follows.

1) Bordered by thick mudstone of the middle and lower Sha 3 Member in the Liaohe Western Sag, there are two sets of fault systems, the lower fault system $\left(\mathrm{E}_{2 \mathrm{~s} 4}-\mathrm{E}_{2 \mathrm{~s} 3}\right)$ and the upper fault system $\left(\mathrm{E}_{3 \mathrm{~s} 1-}\right.$ ${ }_{2}-\mathrm{N}$ ) (Fig. 2, Fig. 4). According to our research, the lower fault system is the consequence of extensional activity in the northwest-southeast direction, whereas the assemblage of the faults of upper fault system could be interpreted by the right-lateral strike-slip strain-ellipse (Fig. 2), which means that the fault system 


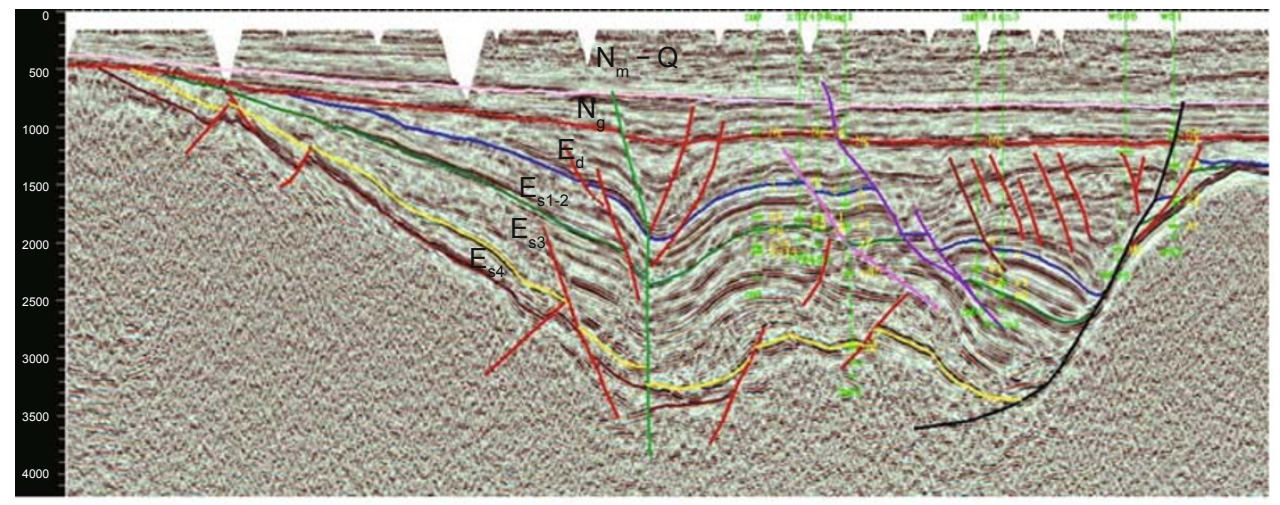

Fig. 5 Structural interpretation profile of inline2166 in the Liaohe Western Sag (negative flower structure developed in the center of profile)

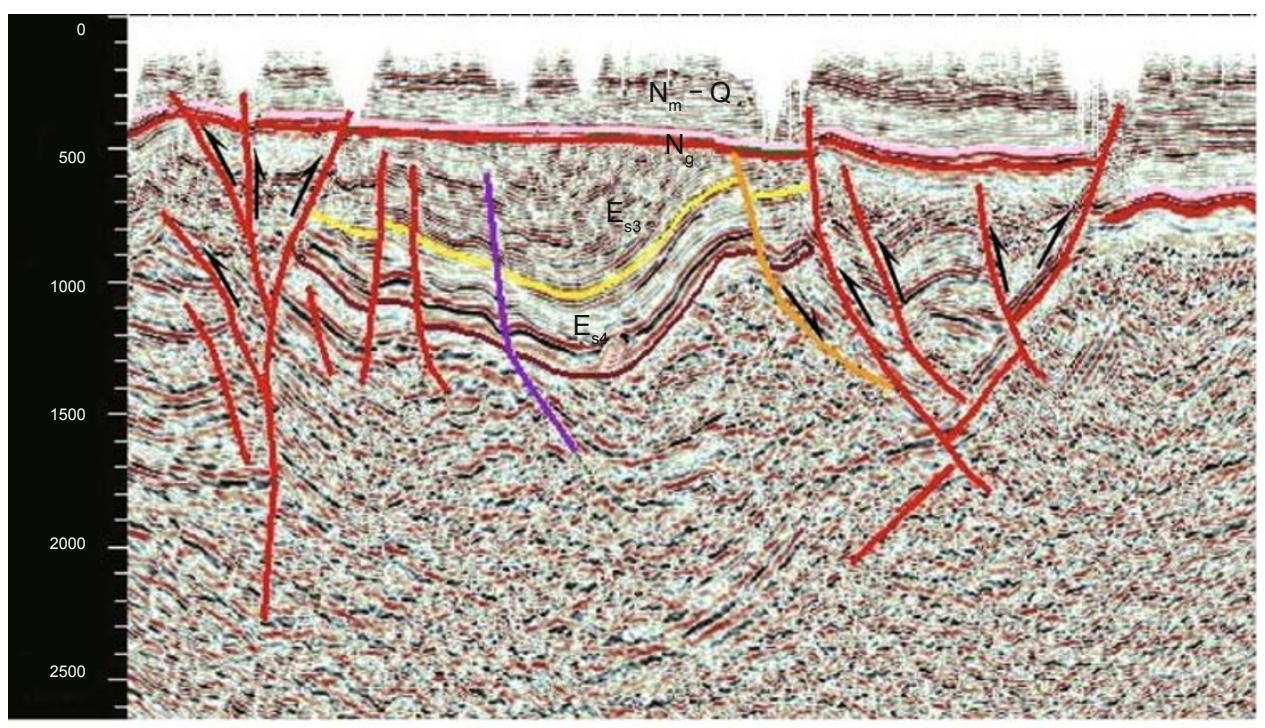

Fig. 6 Structural interpretation profile of inline 4977 in the Liaohe Western Sag (positive flower structure developed in the west side of profile)

of the upper strata was formed under the control of rightlateral strike-slip activity. So the formation, development and evolution of the upper fault system could indicate the strikeslip activity stage and evolution of the Liaohe Western Sag.

2) The upper fault system was developed in the Sha 1-2 $\left(E_{3 s 1-2}\right)$ and upper members, and most of the faults cut down through the thick mudstone of the middle and lower part of Sha 3 Member and then detached, which means that the time of commencement of strike-slip activity is not earlier than $\mathrm{E}_{2 \mathrm{~s} 2}$.

3) Our structural evolution study showed that most of the faults of upper fault system were formed during the Dongying Age and were activated intensively at the end of the Dongying Age (Fig. 7). All of the fault activities after the Dongying Age inherited the activity of the Dongying Age with no exception. The difference is just the obvious decrease of the number of faults, and this reflects the succession and consistency of the structural style and direction after the Neogene. The history of upper fault system activity shows clearly that the right-lateral strike-slip was activated intensively in the Dongying Age and continued to be activated since the Neogene (Table 1).

4) Most of the faults in the present structural contour of Sha 1-2 were activated in Dongying Age and down cut the underlying strata. Only a few faults were activated in the Sha 1-2, including Yuanyanggou Fault, Yuanbei Fault, Taian Dawa Fault, Haiwahei Fault, which have similar characteristics and distribution with those faults in the Dongying Age just with weak intensity. In addition, the distribution of the sedimentary and subsidence center of Sha 1-2 is very different from Sha 3 member, whereas is similar with the Dongying Age. This evidence shows that the structural system of Sha 1-2 did not succeed that of Sha 3 but was influenced by the right-lateral strike-slip regime. Therefore, the right-lateral strike-slip started at Sha 1-2, just with weak intensity.

From the above analysis combined with quantitative analysis, the strike-slip history of the Liaohe Western Sag and its influence on the structural deformation could be summarized as follows (Table 1): The strike-slip activities of the Liaohe Western Sag began in the early Oligocene $\left(\mathrm{E}_{3 \mathrm{s1-2}}\right)$. The activity intensity was weak at the beginning, then was strengthened gradually $\left(\mathrm{E}_{3 \mathrm{~d} 2-3}\right)$ and reached the strongest level 
Table 1 Western Depression tectonic evolution stage

\begin{tabular}{|c|c|c|c|c|c|c|}
\hline \multicolumn{2}{|c|}{ Stragraphic unit } & \multirow{2}{*}{$\begin{array}{c}\text { Basal } \\
\text { age } \\
\text { Ma }\end{array}$} & \multicolumn{2}{|c|}{ Tectonic evolution stage } & \multirow{2}{*}{$\begin{array}{l}\text { Tectonic } \\
\text { deformation } \\
\text { pattern }\end{array}$} & \multirow{2}{*}{$\begin{array}{l}\text { Faulting } \\
\text { intensity }\end{array}$} \\
\hline System & $\begin{array}{c}\text { Formation } \\
\text { and unit }\end{array}$ & & Stage & Age & & \\
\hline \multirow{2}{*}{ Neogene } & $\mathrm{N}_{2 \mathrm{~m}}$ & 5.1 & \multirow{2}{*}{ Depression } & \multirow{2}{*}{ Depression } & \multirow{3}{*}{$\begin{array}{l}\text { Strike } \\
\text { slip }\end{array}$} & \\
\hline & $\mathrm{N}_{1 \mathrm{~g}}$ & 23.3 & & & & \\
\hline \multirow{4}{*}{ Eogene } & $\mathrm{E}_{3 \mathrm{~d}}$ & 36 & \multirow{4}{*}{ Rifting } & $\begin{array}{c}\text { Elevation and } \\
\text { subsidence }\end{array}$ & & \\
\hline & $\mathrm{E}_{3 \mathrm{~s} 1-2}$ & 38 & & $\begin{array}{c}\text { Faulting } \\
\text { depression }\end{array}$ & \multirow{3}{*}{ Extension } & \\
\hline & $\mathrm{E}_{3 \mathrm{~s} 3}$ & 43 & & $\begin{array}{c}\text { Strong faulting } \\
\text { depression }\end{array}$ & & \\
\hline & $\mathrm{E}_{3 \mathrm{~s} 4}$ & 45.4 & & Initial rifting & & \\
\hline
\end{tabular}

Notes: line thickness on the right side in table represents the different strength of fault activity in different stages

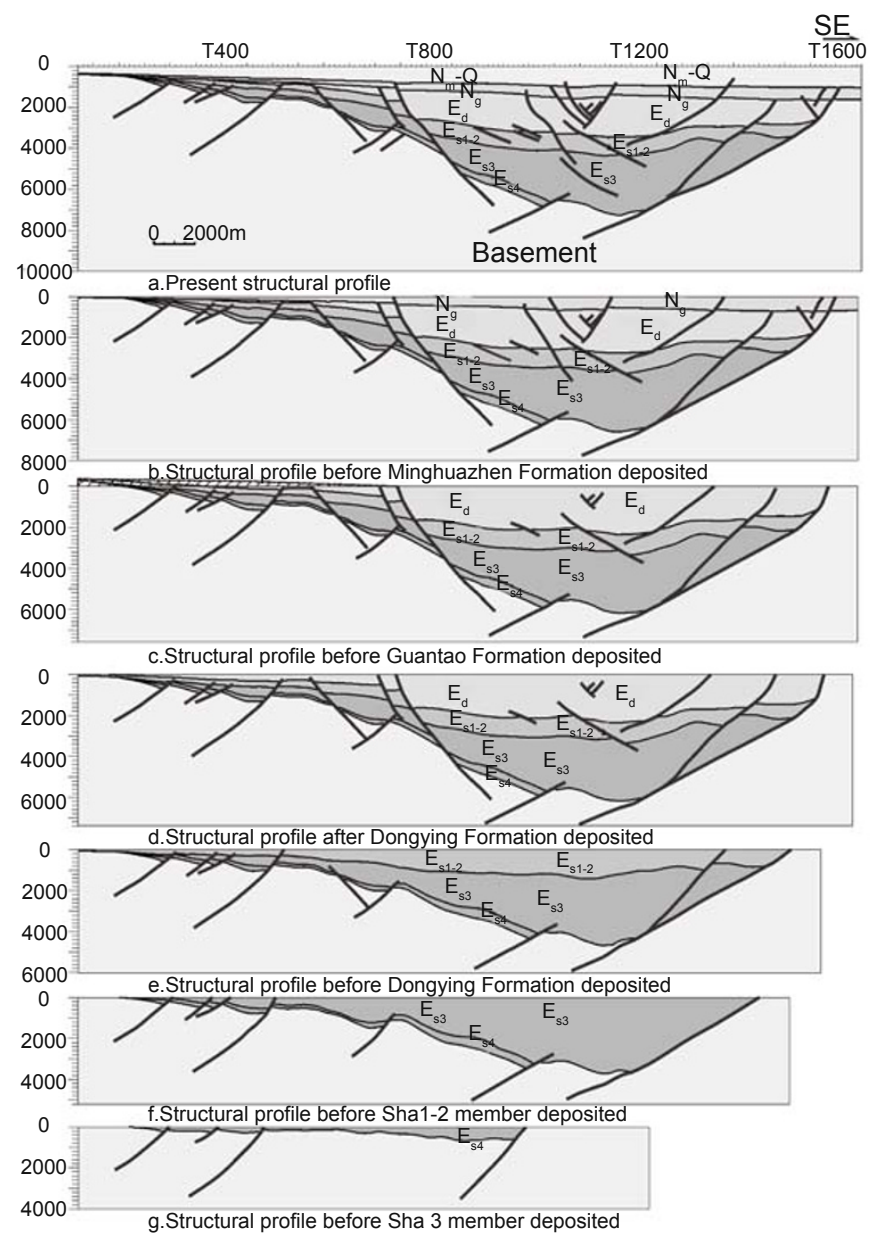

Fig. 7 Inline746 tectonic evolution profile of Liaohe Western Sag (line location see Fig. 2)

in the late Oligocene $\left(\mathrm{E}_{3 \mathrm{~d} 1}\right)$. There was just a little strikeslip activity in the Miocene $\left(\mathrm{N}_{1 \mathrm{~g}}\right)$ and was strengthened significantly once again in the Pliocene $\left(\mathrm{N}_{2 \mathrm{~m}}-\mathrm{Q}\right)$.
The right-lateral strike-slip of the Liaohe Western Sag, which started from the Oligocene is consistent with the result of regional studies of the Tanlu Fault (Xu et al, 1984; 1987; 1995; Xu and Ma, 1992; Xu, 1993), while on the other hand, it is in accordance with the time point (40Ma) of the change of Asian-Pacific plate's movement mechanism, which was caused by the collision between Indian Plate and Euro-Asian Plate (Jin, 1981). This proves that the change of activity style of the Tanlu Fault after the Oligocene in the Cenozoic is consistent with the change of movement mechanism resulting from the collision of Indian Plate and Euro-Asian Plate.

\section{Conclusions and discussion}

1) There is a variety of structural features related to right-lateral strike-slip activity in the Liaohe Western Sag, including a significant basin-sized echelon normal faults zone, development of "comb" structures, existence of typical symbols of strike-slip, co-existence of all kinds of structural styles and co-existence of "interpretable" and "buried" strikeslip faults. All these characteristics provide reliable evidence of existence of strike-slip faults.

2) Right-lateral strike-slip is the major type of strike-slip activity with different appearances in different areas, which appear to be strike-slip tenso-shear in the south, compressoshear and tenso-shear complex area in the center and compresso-shear in the north.

3) The strike-slip activities began in the early Oligocene. The activity intensity was weak at the beginning $\left(\mathrm{E}_{3 \mathrm{sl}-2}\right)$, then was strengthened gradually and reached its strongest level in the late Oligocene $\left(E_{3 \mathrm{~d} 1}\right)$. There was just a little strike-slip activity in the Miocene, which was strengthened significantly once again in the Pliocene. It is speculated that the entire northern section of the Tanlu Fault had a similar evolution history since the Oligocene.

\section{References}


Hong $\mathrm{Z} \mathrm{M}$ and Yang $\mathrm{Z}$ J. The history of generation, development and evolution of the Tancheng-Lujiang fracture in Liaoning province. Geological Bulletin of China. 1984. 10(3): $49-57$ (in Chinese)

Jin X C. Plate tectonics foundation. Shanghai: Shanghai Science and Technology Press. 1981. 78-93 (in Chinese)

Li X G, Zhang J C, Chen Z Y, et al. Petroleum system and natural gas distribution in Western Depression of Liaohe Sub-basin. Natural Gas Industry. 2007. 27(5): 39-43 (in Chinese)

Liao X M and Yao J F. The tectonic evolution and oil and gas of Liaohe Depression. Beijing: Petroleum Industry Press. 1996. 12-26 (in Chinese)

Lu K Z, Qi J F, Dai J S, et al. Cenozoic tectonic model in Bohai Bay petroliferous basins. Beijing: Geological Publishing House. 1997. 72-86 (in Chinese)

Ma W P. The latest summary of Tanlu Fault research. Geological Review. 1995. 41(5): 480-481 (in Chinese)

Meng Q R. What drove late Mesozoic extension of the northern ChinaMongolia tract? Tectonophysics. 2003. 369 (3-4): 155-174

Qi J F. Structural analysis of Cenozoic rift basin in Xialiaohe-Liaodong Bay. Beijing: Geological Press. 1995. 1-33 (in Chinese)

Shan J F, Chen Z Y and Hui X F. Forming conditions of lithologic reservoir in transition zone of western Liaohe Depression. Petroleum Exploration and Development. 2005. 32(6): $42-45$ (in Chinese)

Xu J W, Cui K R, Zhu G, et al. Some progress of displacement research of the Tanlu Fault system, eastern China. Journal of Hefei University of Technology (Natural Scienc Edition). 1984. (2): 28-37 (in Chinese)
Xu J W and Ma G F. Review of ten years of research on the TanchengLujiang Fault zone. Geological Review. 1992. 38(4): 316-324 (in Chinese)

Xu J W, Zhu G, Lu P J, et al. Progress in studies on strike-slip chronology of the Tanlu Fault zone. Geology of Anhui. 1995. 5(1): 1-12 (in Chinese)

Xu J W, Zhu G, Tong W X, et al. Formation and evolution of the Tancheng-Lujiang wrench fault system: a major shear system to the northwest of the Pacific Ocean. Tectonophysics. 1987. 134(4): 273-310

Xu J W. The Tancheng-Lujiang wrench fault system. Chichester (UK): John Wiley \& Sons Ltd. 1993. 1-15

Yang X, Yang Q and Yu F S. Calculation of the denudation amount of the Paleogene in the north part of the west depression, Liaohe Basin. Journal of Xi' an Petroleum University (Natural Science Edition). 2006. 21(5): 34-39 (in Chinese)

Yao Y Z and Fang Z J. "Tanlu Fault colloquium" note. Seismology and Geology. 1981. 3(2): 69-78 (in Chinese)

You G Q, Pan J H, Zhang K B, et al. An analysis of the conditions for the formation of oil and gas accumulations in northern Gaosheng area within the western depression of Liaohe Sag. Acta Geoscientica Sinica. 2006. 27(3): 241-246 (in Chinese)

Yu F S, Ji Z W, Yang X, et al. Cenozoic fault feature and trap styles of northern area in west depression of Liaohe Basin. Journal of Earth Science and Environment. 2007. 29(2): 149-153 (in Chinese)

(Edited by Hao Jie) 